\title{
Comparison of analysis and design of regular and irregular configuration of multi Story building in various seismic zones and various types of soils using ETABS and STAAD
}

\author{
Mr. S.Mahesh ${ }^{1}$, Mr. Dr.B.Panduranga Rao ${ }^{2}$ \\ ${ }^{I}$ (Department of Civil Engineering/V R Siddhartha Engineering College, India) \\ ${ }^{2}$ (Department of Civil Engineering/V R Siddhartha Engineering College, India)
}

\begin{abstract}
The behaviour of G+11 multi story building of regular and irregular configuration under earth quake is complex and it varies of wind loads are assumed to act simultaneously with earth quake loads. In this paper a residential of G+11 multi story building is studied for earth quake and wind load using ETABS and STAAS PRO V8i.Assuming that material property is linear static and dynamic analysis are performed. These analysis are carried out by considering different seismic zones and for each zone the behaviour is assessed by taking three different types of soils namely Hard, Medium and Soft .Different response like story drift, displacements base shear are plotted for different zones and different types of soils.
\end{abstract}

Keywords: Regular and irregular configuration, static \& dynamic analysis

\section{Introduction}

A. Concept Of Regular And IrRegular Configuration:

To perform well in an earth quake a building should possess four main attributes namely simple and regular configuration and adequate lateral Strength, stiffness and ductility. Buildings having simple regular geometry and uniformly distributed mass and stiffness in plan as well as elevation, suffer much less damage than buildings with irregular configuration. A building shall be considered as irregular for the purposes of this standard, if at least one of the conditions are applicable as per IS 1893(part1):2002

\author{
B. The Procedures For The Earthquake Analysis Of The Structures: \\ - Linear Static Procedure \\ - Linear dynamic Procedure \\ - Response Spectrum method \\ - Time history method \\ - Nonlinear Static Procedure (Pushover analysis) \\ - Nonlinear dynamic procedure \\ As per IS-1893:2002, Methods Adopted are \\ - Equivalent Static Lateral Force (or) Seismic Coefficient Method \\ - Response Spectrum Method \\ - Time history method
}

\section{Linear Static Procedure:}

The linear static procedure of building is modelled with their linearly elastic stiffness of the building. The equivalent viscous damps the approximate values for the lateral loads to near the yield point. Design earthquake demands for the LSP are represented by static lateral forces whose sum is equal to the pseudo lateral load. When it is applied to the linearly elastic model of the building it will result in design displacement amplitudes approximating maximum displacements that are expected during the design earthquake. To design the earth quake loads to calculate the internal forces will be reasonable approximate of expected during to design earth quake.

\section{RESPONSE SPECTRUM METHOD:}

I. The representation of the maximum response of idealized single degree freedom system having certain period and damping, during earthquake ground motions. The maximum response plotted against of undamped natural period and for various damping values and can be expressed in terms of maximum absolute acceleration, maximum relative velocity or maximum relative displacement. For this purpose response spectrum case of analysis have been performed according to IS 1893 


\section{DEFINITIONS}

Storey: when the multi story building or the residential building is constructed in that when the floor to floor gap will be their that is the story.

Storey Shear (VI): We will calculated all the lateral loads at each floor of the building

Story Drift: is defined as the difference in lateral deflection between two adjacent stories. During an earthquake, large lateral forces can be imposed on structures; Lateral deflection and drift have three primary effects on a structure; the movement can affect the structural elements (such as beams and columns); the movements can affect non-structural elements (such as the windows and cladding); and the movements can affect adjacent structures. Without proper consideration during the design process, large deflections and drifts can have adverse effects on structural elements, nonstructural elements, and adjacent structures

\section{A. Effect Of Drift On The Structure:}

In terms of seismic design, lateral deflection and drift can affect both the structural elements that are part of the lateral force resisting system and structural elements that are not part of the lateral force resisting system. In terms of the lateral force resisting system, when the lateral forces are placed on the structure, the structure responds and moves due to those forces. Consequently, there is a relationship between the lateral force resisting system and its movement under lateral loads; this relationship can be analyzed by hand or by computer. Using the results of this analysis, estimates of other design criteria, such as rotations of joints in eccentric braced frames and rotations of joints in special moment resisting frames can be obtained. Similarly, the lateral analysis can also be used and should be used to estimate the effect of lateral movements on structural elements that are not part of the lateral force resisting system, such as beams and columns that are not explicitly considered as being part of the lateral force resisting system. Design provisions for moment frame and eccentric braced frame structures have requirements to ensure the ability of the structure to sustain inelastic rotations resulting from deformation and drift. Without proper consideration of the expected movement of the structure, the lateral force resisting system might experience premature failure and a corresponding loss of strength. In addition, if the lateral deflections of any structure become too large, $\mathrm{P}-\Delta$ effects can cause instability of the structure and potentially result in collapse.

\section{B. Center Of Mass:}

The center of mass is the unique point at the center of a distribution of mass in space that has the property that the weighted position vectors relative to this point sum to zero. In analogy to statistics, the center of mass is the mean location of a distribution of mass in space.

\section{Center Of Rigidity:}

Answer: Center of rigidity is the stiffness centroid within a floor-diaphragm plan. When the center of rigidity is subjected to lateral loading, the floor diaphragm will experience only translational displacement. Other levels are free to translate and rotate since behavior is coupled both in plan and along height. As a function of structural properties, center of rigidity is independent of loading. Certain building codes require center of rigidity for multistory-building design-eccentricity requirements.

For a given floor diaphragm, center of rigidity is calculated through the following process:

Case 1 applies a global-X unit load to an arbitrary point, perhaps the center of mass, such that the diaphragm rotates Rzx.

Case 2 applies a global-Y unit load at the same point, causing rotation Rzy.

Case 3 applies a unit moment about global-Z, causing rotation Rzz. These three load cases are shown in Figure 1

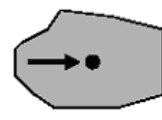

Case 1: $F x=1$

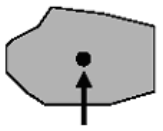

Case 2: Fy $=1$

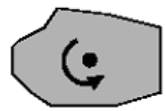

Case 3: $\mathrm{Mz}=1$

Center of rigidity $(\mathrm{X}, \mathrm{Y})$ is then computed as $\mathrm{X}=-\mathrm{Rzy} / \mathrm{Rzz}$ and $\mathrm{Y}=\mathrm{Rzx} / \mathrm{Rzz}$.

\section{Seismic weight of building:}

The seismic weight of the building means that is calculated on the entire floors weight of the building

Fundamental Natural period as per IS 1893(part1):2002

1. The approximate fundamental natural period of vibration (Ta)in seconds of a moment resisting frame building without brick infill panels may be estimated by the empirical expression

$\mathrm{Ta}=0.075 \mathrm{~h}^{\wedge} 0.75$ for $\mathrm{RC}$ framed building

$\mathrm{Ta}=0.075 \mathrm{~h}^{\wedge} 0.75$ for steel framed building

Where $\mathrm{h}=$ height of building 
2. The approximate fundamental natural period of vibration (Ta) in seconds, of all other buildings, including moment -resisting frame buildings with brick infill panels, may be estimated by the empirical expression:

$$
\mathrm{Ta}=0.09 \mathrm{~h} / \sqrt{\mathrm{d}}
$$

Where $\mathrm{h}=$ height of building

$\mathrm{d}=$ Base dimensions of the building at the plinth level in $\mathrm{m}$, along the considered direction of lateral force

\section{E. Design Seismic Base Shear:}

The total design lateral force or design seismic base shear $(\mathrm{Vb})$ along any principal direction shall be determined by the following expression

$\mathrm{Vb}=\mathrm{AhXW}$

Where $\mathrm{Ah}=$ Design horizontal acceleration spectrum value as per clause 6.4.2 IS 1893(part1):2002 using the fundamental natural period Ta as per clause 7.6 IS 1893(part 1):2002 in the consider direction of vibration

$\mathrm{W}=$ Seismic weight of building

Here

$\mathrm{Ah}=\left(\frac{\mathrm{z}}{2}\right) \times\left(\frac{\mathrm{I}}{\mathrm{R}}\right) \times\left(\frac{\mathrm{Sa}}{\mathrm{g}}\right)$

$\mathrm{Z}=$ zone factor

$\mathrm{I}=$ Importance factor

$\frac{\text { Sa }}{\mathrm{g}}=$ is depending up on the Ta and type of soil

\section{F. Load combination:}

In the limit state design of reinforced and prestressed concrete structures, the following load combinations shall be accounted for as per IS1893 (part1):2002

1. $1.5(\mathrm{DL}+\mathrm{IL})$

2. $1.2(\mathrm{DL}+\mathrm{IL} \pm \mathrm{EL})$

3. $1.5(\mathrm{DL} \pm \mathrm{EL})$

4. 4 0.9DL $\pm 1.5 \mathrm{EL}$

\begin{tabular}{|l|l|}
\hline \multicolumn{2}{|l|}{ Irregular Configuration } \\
\hline X Direction & $2.43,3,2.43,3,2.43,3,2.43,3$ \\
\hline Y Direction & $3.65,4.11,3.65,4.11,3.65$ \\
\hline Regular Configuration \\
\hline X Direction & $3.5,3.5,3.5,3.5,3.5,3.5,3.5,3.5$ \\
\hline Y Direction & $3.5,3.5,3.5,3.5,3.5$ \\
\hline
\end{tabular}

\section{Material Properties For Regular And Irregular Configuration}

Grade of concrete M25

Grade of steel Fe 500

Column sizes $=0.30 \mathrm{X} 0.90 \mathrm{mts}$

Beam sizes $=0.30 \mathrm{X} 0.65$ meters

Slab thickness $=0.125$ meters

Number of stories $=\mathrm{G}+11$

Number of bays along X-direction $=8$

Number of bays along Y-direction $=5$

Storey height $=4$ meters

Plinth height $=2$ meters

Bay width along $\mathrm{X}$-direction $=28$ meters for regular configuration

Bay width along $\mathrm{Y}$-direction $=17.5$ meters for regular configuration

Bay width along $\mathrm{X}$-direction $=21.72$ meters for irregular configuration

Bay width along Y-direction $\quad=19.17$ meters for irregular configuration

Loading parameters

Wall load for the outer side $=15.41 \mathrm{kN} / \mathrm{m}$

Wall load for the inner side $=7.705 \mathrm{kN} / \mathrm{m}$

Wall load for the terrace $=4 \mathrm{kN} / \mathrm{m}$

Dead load of slab $=4.625 \mathrm{kN} / \mathrm{m} 2$

Live load $=4 \mathrm{kN} / \mathrm{m} 2$

For Seismic loading only $50 \%$ of the imposed load is considered the structure is analyzed for all seismic zones by considering three different types of soils namely Hard Medium and Soft for each seismic zone

For wind load the risk coefficient is taken as 1and as per IS 873 the terrain category is 2 and class of the structure is $\mathrm{B}$, the topography of the structure is 1 
Comparison of analysis and design of regular and irregular configuration of multi Story building ...

\begin{tabular}{|c|c|c|}
\hline \multicolumn{3}{|c|}{$\mathrm{Sa} / \mathrm{g}$ value for the regular configuration } \\
\hline Type of soil & Fundamental time period $\mathrm{Tx}$ & Fundamental time period Ty \\
\hline Rock & 1.176 & 0.930 \\
\hline Medium & 1.6 & 1.265 \\
\hline Soft & 1.96 & 1.553 \\
\hline
\end{tabular}

\section{Irregular Configuration}

\begin{tabular}{|l|l|l|}
\hline \multicolumn{2}{|l|}{ Sa/g value for the irregular configuration } \\
\hline Type of soil & $\begin{array}{l}\text { Fundamental time } \\
\text { period Tx }\end{array}$ & $\begin{array}{l}\text { Fundamental time } \\
\text { period Ty }\end{array}$ \\
\hline Rock & 1.036 & 0.956 \\
\hline Medium & 1.409 & 1.301 \\
\hline Soft & 1.730 & 1.598 \\
\hline
\end{tabular}

\section{Plan of the building \& 2.3D VIEW of the building}

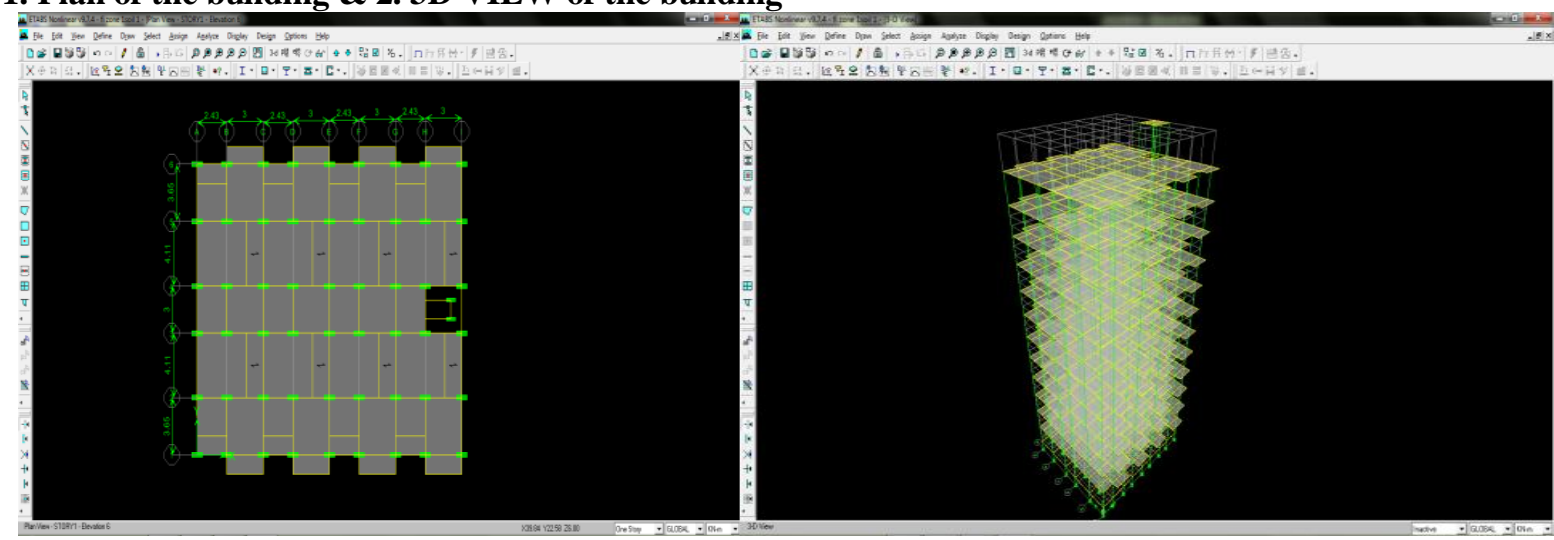

3. Elevation of building

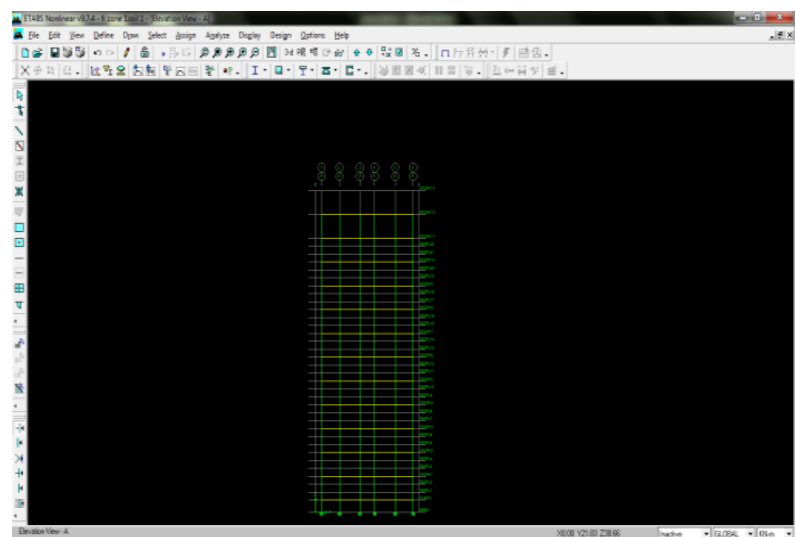

4. STAAD plan

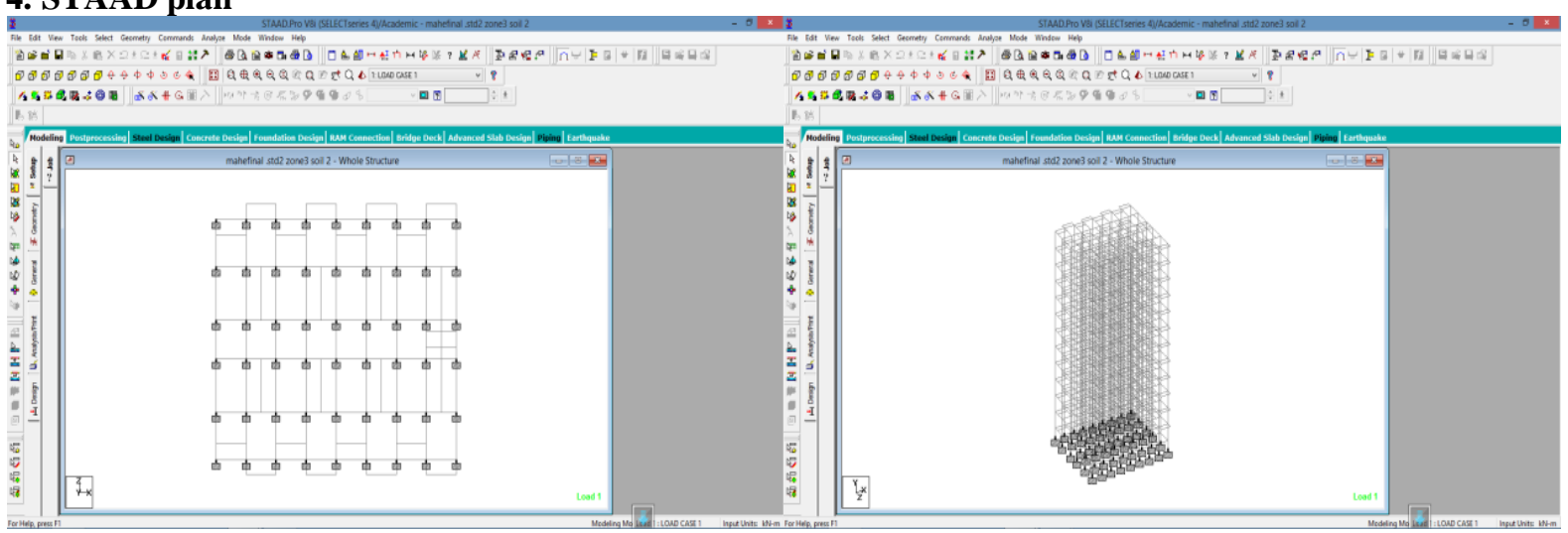




\section{Regular Configuration}

I have taken as $3.5 \mathrm{mts}$ each bay along $\mathrm{X}$ and $\mathrm{Y}$

1. Plan of building \& 2.Elevation

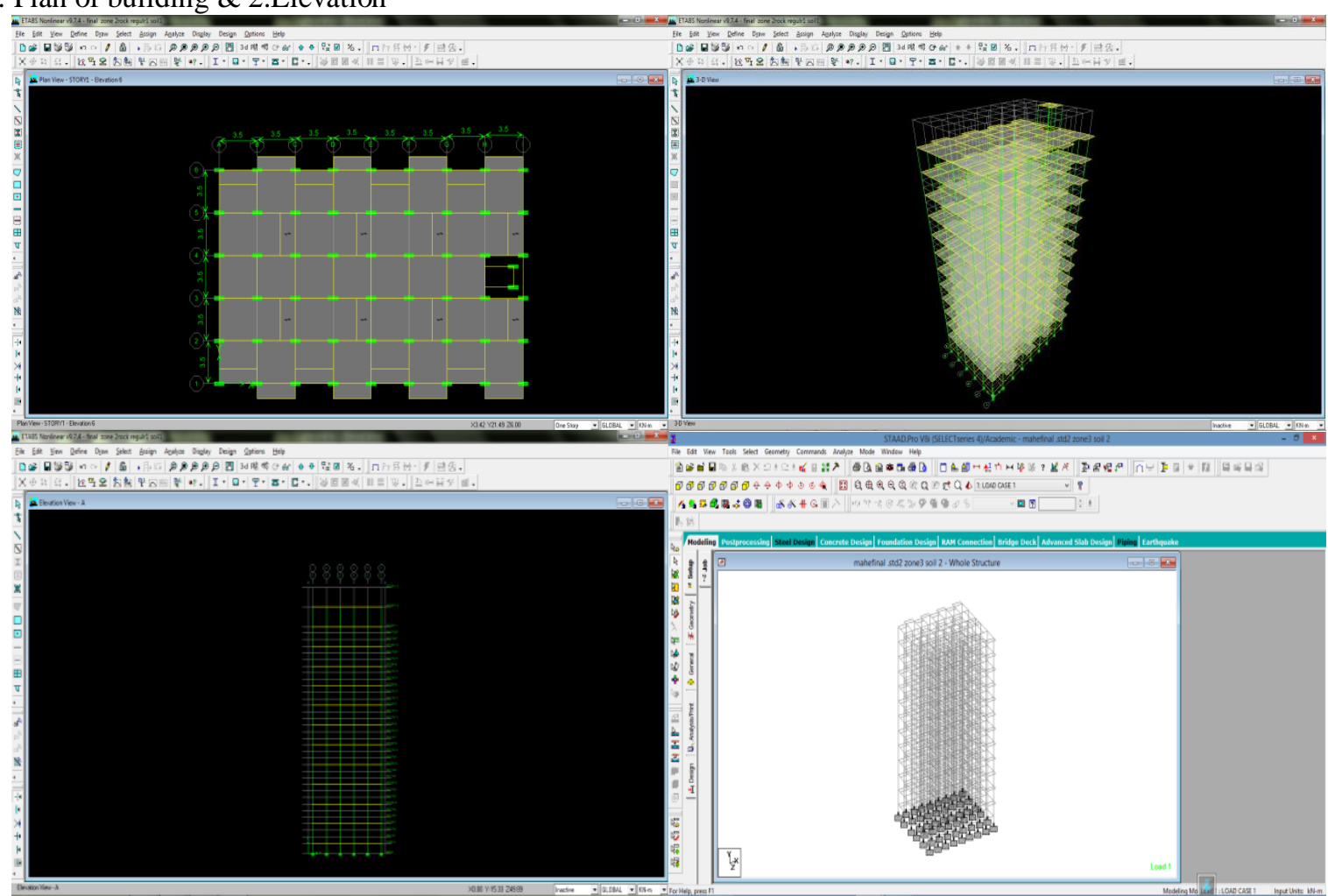

1. Irregular configuration

\section{Graphs}

\section{ETABS}
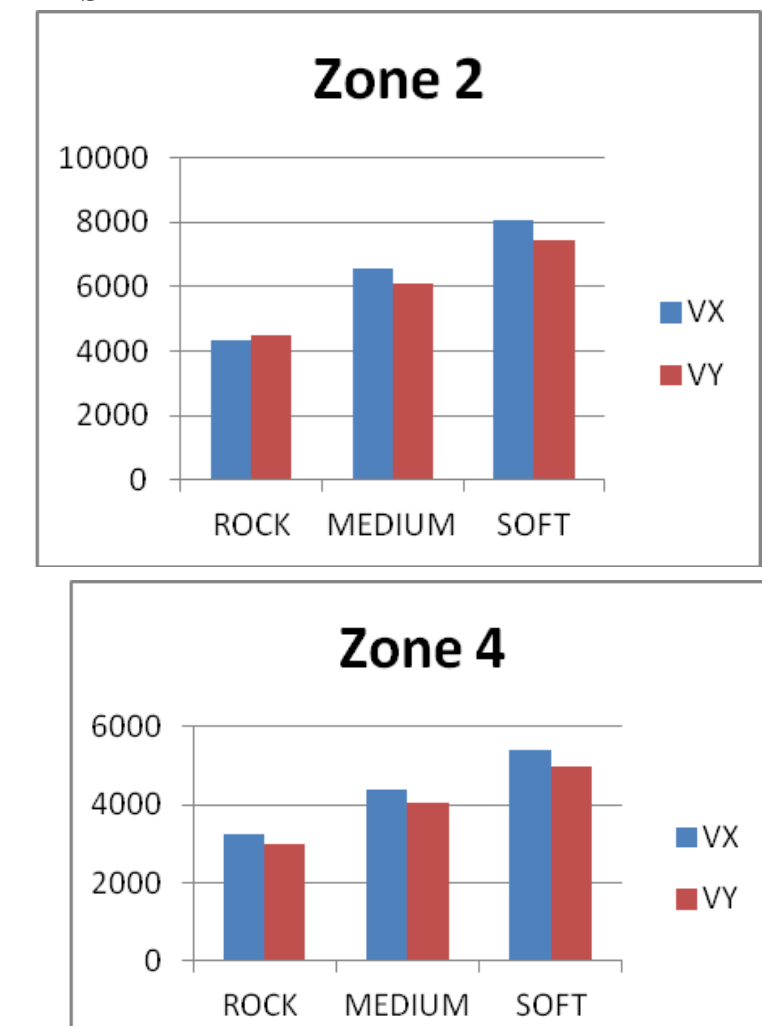

\section{Zone 3}

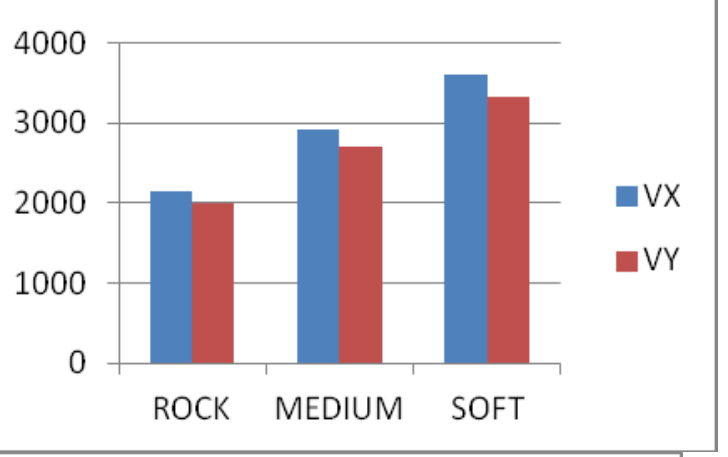

\section{Zone 5}

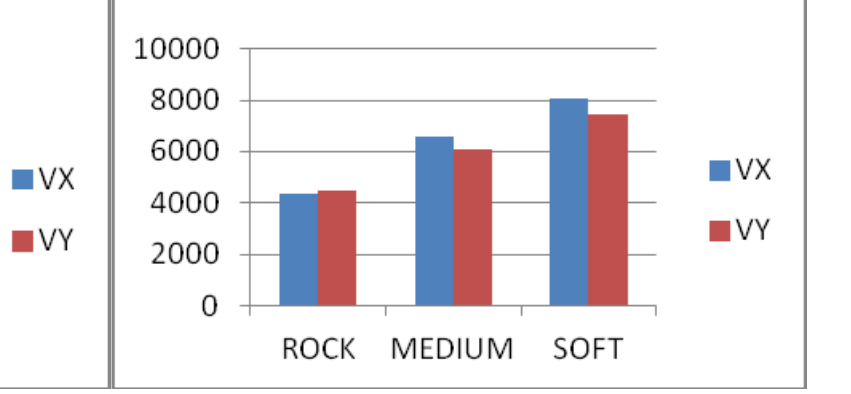

STAAD PRO 


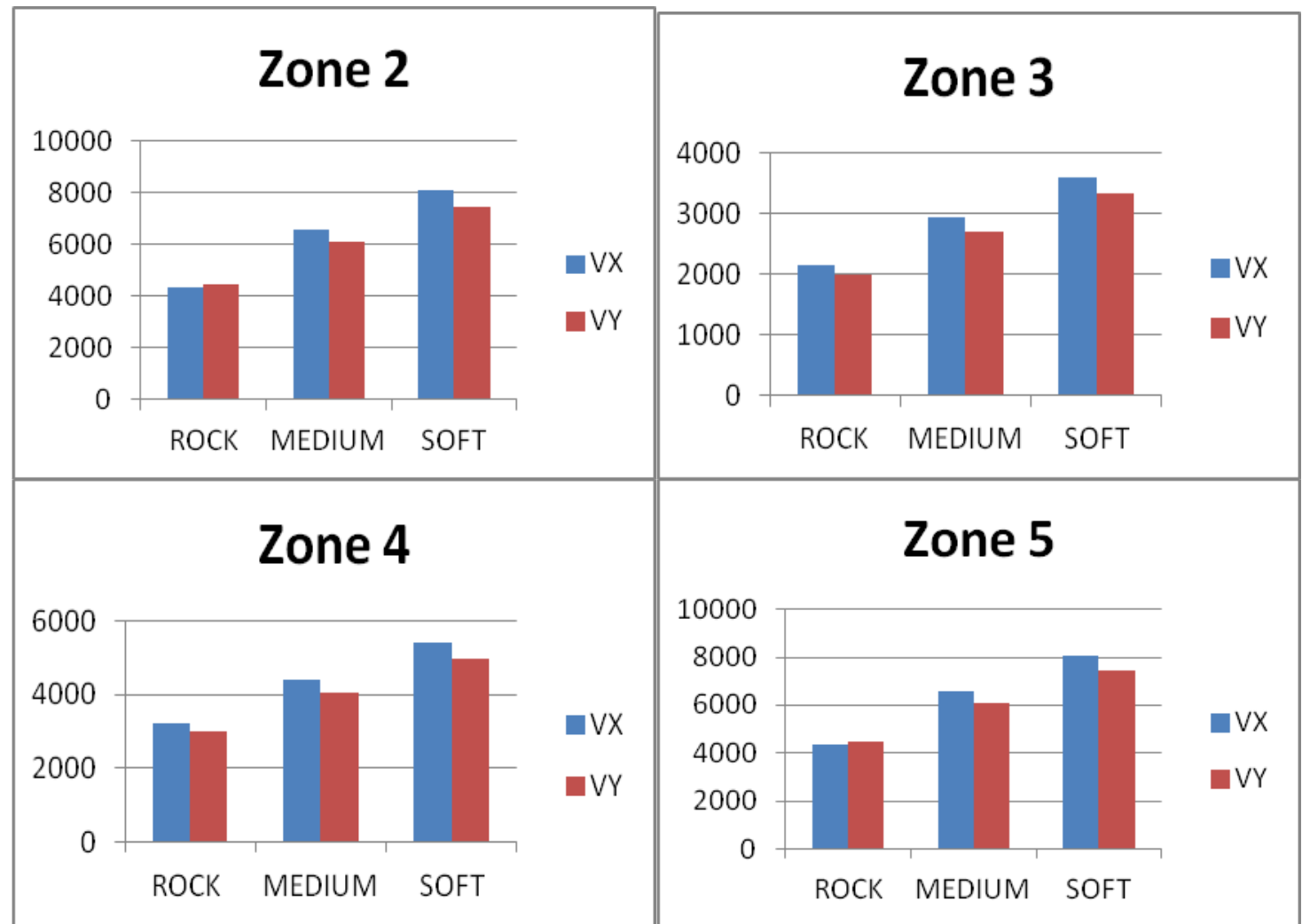

Story drift for the worst combination for all zones and all type of soils

ETABS \& STAAD PRO

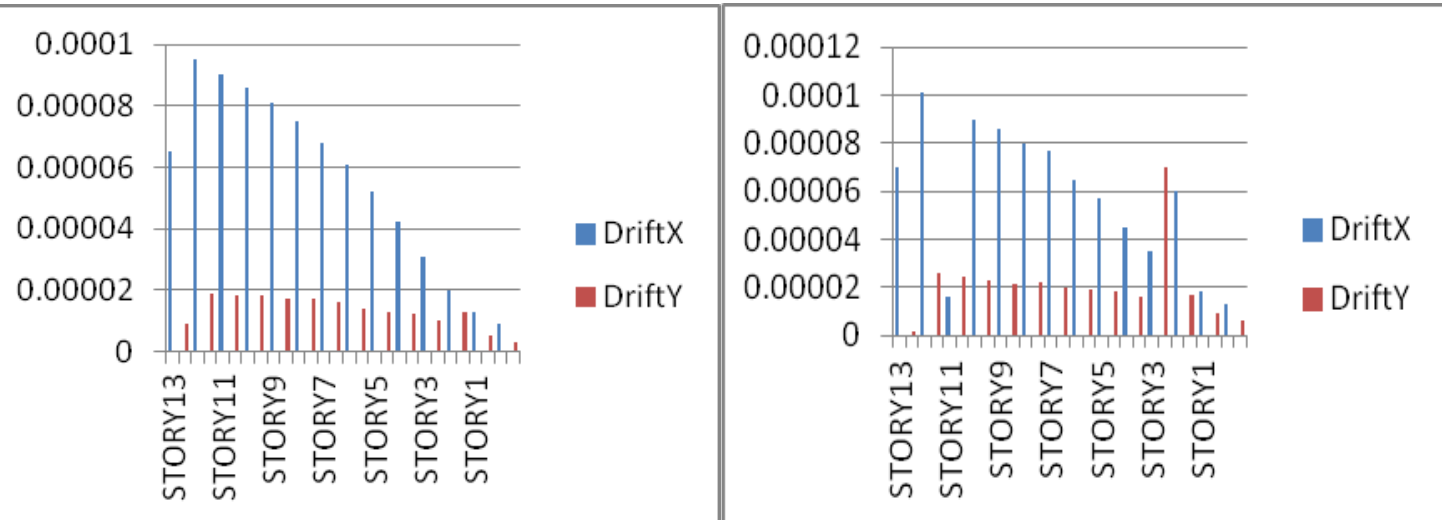

\section{For regular configuration}

\section{ETABS}

Base shear

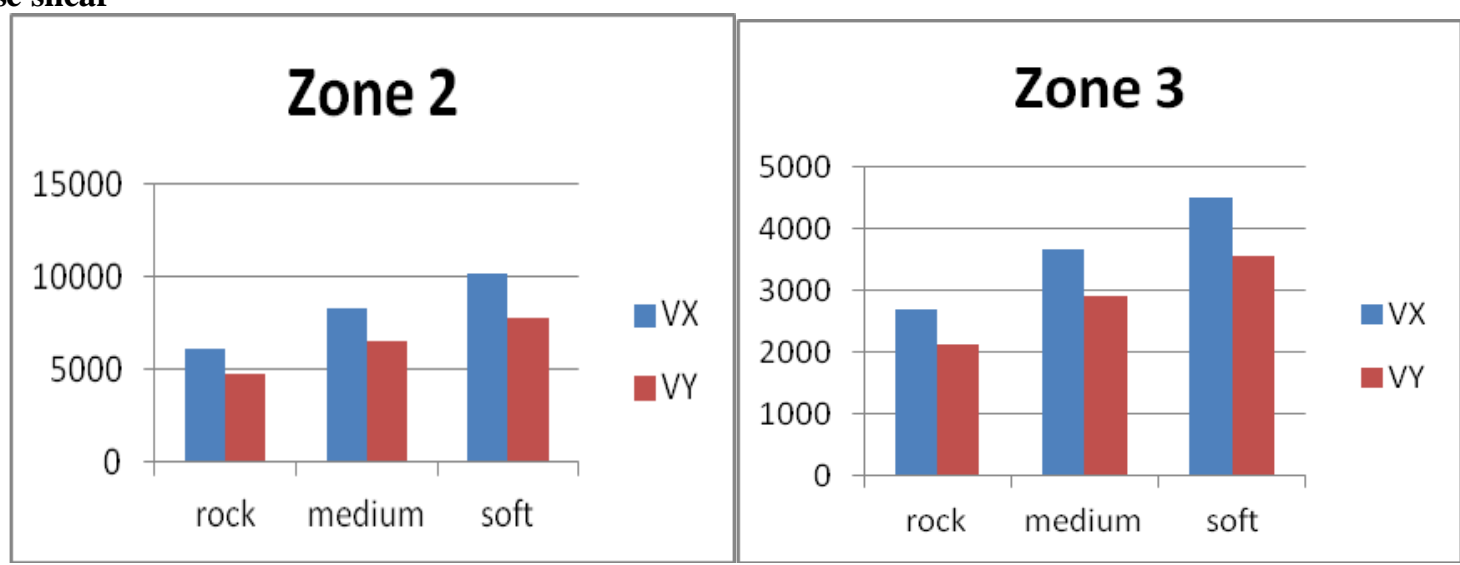




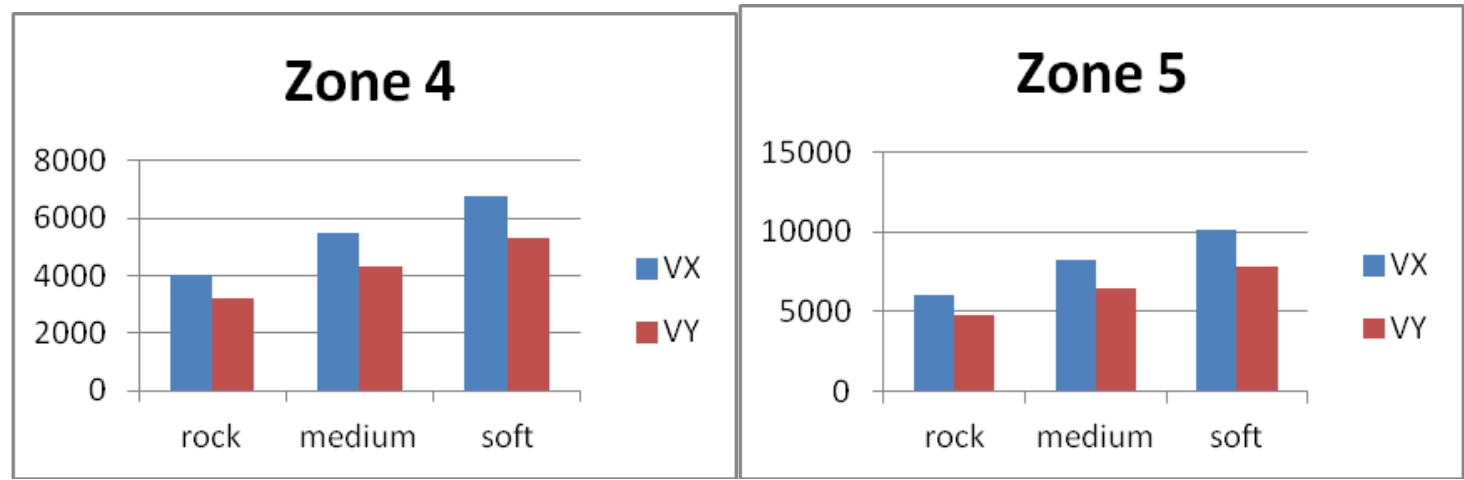

STAAD PRO

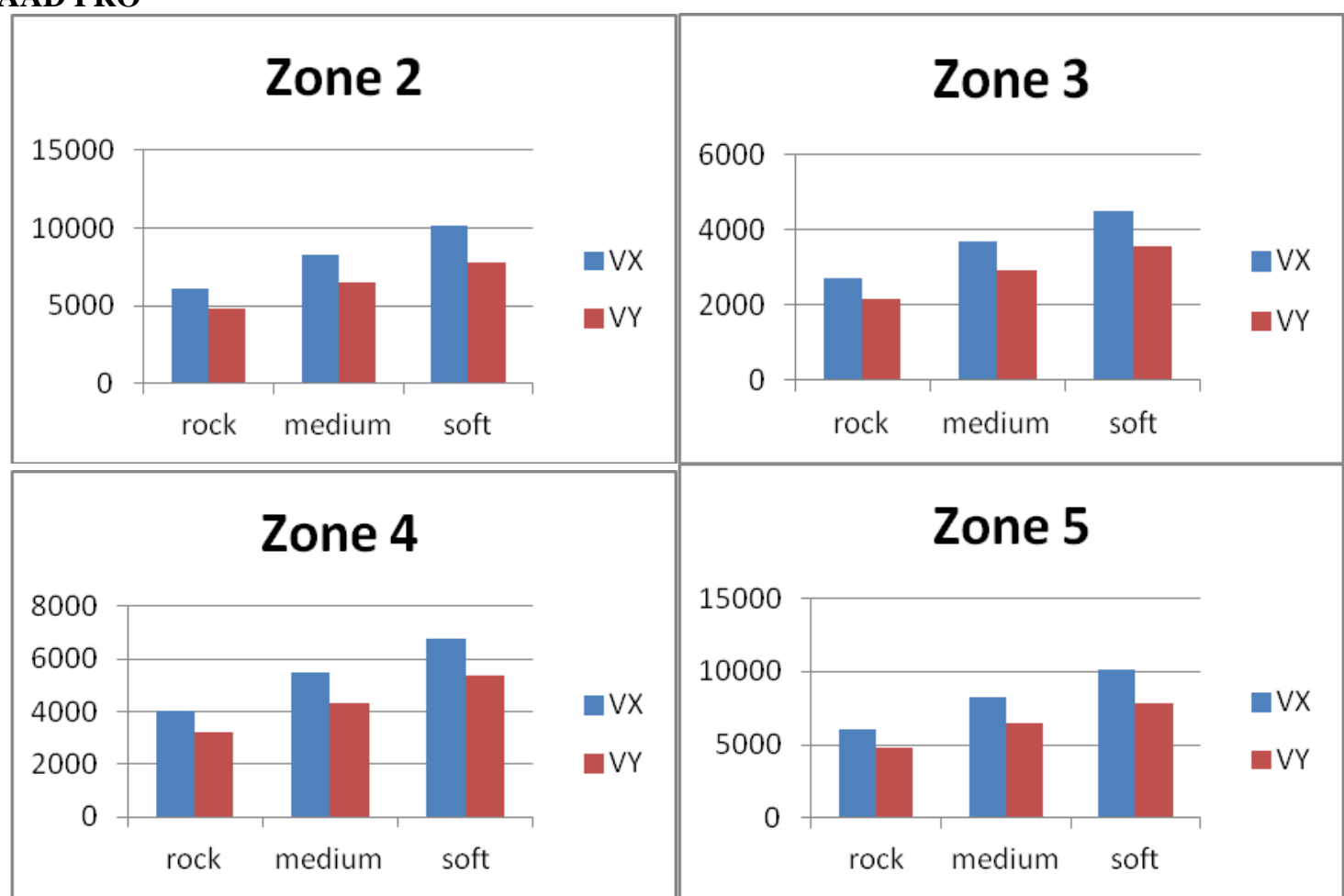

Story drift for the worst combination for all zones and all types of soils

\section{ETABS \& STAAD}

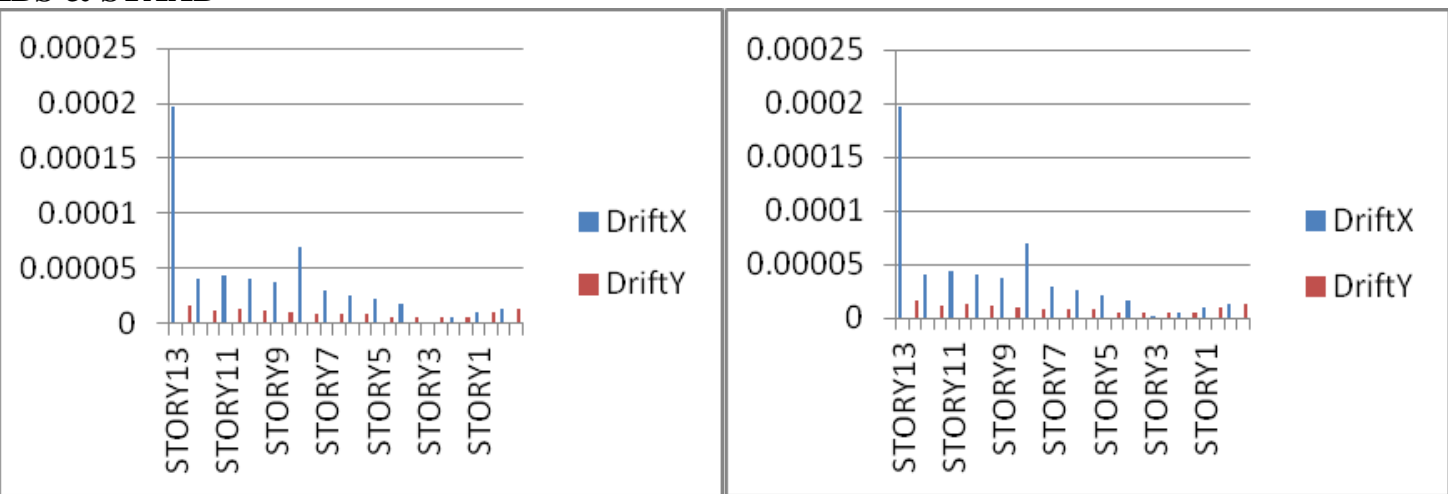

VII. Conclusion

1 .Base shear value is more in the zone 5 and that in the soft soil in irregular configuration.

2. Base shear value is more in the zone 5 and that in the soft soil in regular configuration

3. When compared the both the regular and irregular configuration and the base shear value is more in the regular configuration. Because of the structure have more symmetrical dimensions. 
4. Story drift value is more in the story 12 in the irregular configuration.

5. Story drift value is more in the story 13 in the regular configuration.

6. When compared the both the regular and irregular configuration and the story drift value is more in the regular configuration. Because of the structure has more dimensions.

7. Finally when compared the both software's the STAAD PROV8i has more value. The area of the steel is 5 to $10 \%$

\section{References}

[1]. "Comparative Study of the Static and Dynamic Analysis of Multi-Storey Irregular Building" Bahador Bagheri, Ehsan Salimi Firoozabad, and Mohammadreza Yahyaei

[2]. Static and Dynamic Behaviour of Reinforced Concrete Framed Building: A Comparative Study

[3]. Prakash Sangamnerkar*, Dr. S. K. Dubey,

[4]. Design Cell,M. P. Housing and Infrastructure Development Board, Bhopal (M.P.) 462013

[5]. Professor, Deptt. Of Civil Engineering, Maulana Azad National Institute of Technology, Bhopal (M.P.) 462051

[6]. Response Analysis of Multi-Storey RC Buildings under Equivalent Static and Dynamic Loads According to Egyptian Code Sayed Mahmoud1, Waleed Abdallah2 1Department of Construction Engineering, College of Engineering, Dammam University Dammam, Saudi Arabia 2Faculty of Engineering at Mataria, Helwan University Cairo, Egypt

[7]. Static and Dynamic Behavior of Reinforced Concrete Framed Building: A Comparative Study

[8]. Prakash Sangamnerkar*, Dr. S. K. Dubey

[9]. Design Cell,M. P. Housing and Infrastructure Development Board, Bhopal (M.P.) 462013

[10]. Professor, Deptt. Of Civil Engineering, Maulana Azad National Institute of Technology, Bhopal (M.P.)

[11]. Bureau of Indian Standards:IS-875,part (1) 1987,Dead loads on Buildings and Structures, New Delhi, India

[12]. Bureau of Indian Standards:IS-875,part (2) 1987, Live loads on Buildings and Structures, New Delhi, India

[13]. Bureau of Indian Standards:IS-1893, part (1) 2002,Criteriaof Eqrth quakeResitant Design of Structures: part 1 General provisions on Buildings, New Delhi, India 